\title{
BNFL Report Glass Formers Characterization
}

by

R. F. Schumacher

Westinghouse Savannah River Company

Savannah River Site

Aiken, South Carolina 29808

R. Hayden (Contact)

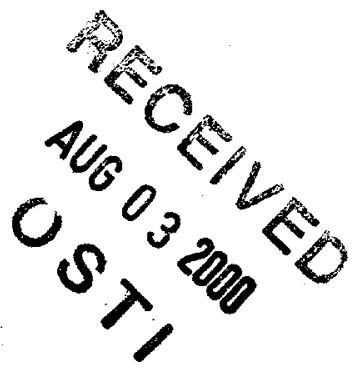

DOE Contract No. DE-AC09-96SR18500

This paper was prepared in connection with work done under the above contract number with the U.S.

Department of Energy. By acceptance of this paper, the publisher and/or recipient acknowledges the U.S.

Government's right to retain a nonexclusive, royalty-free license in and to any copyright covering this paper, along with the right to reproduce and to authorize others to reproduce all or part of the copyrighted paper. 


\section{DISCLAIMER}

This report was prepared as an account of work sponsored by an agency of the United States Government. Neither the United States Government nor any agency thereof, nor any of their employees, makes any warranty, express or implied, or assumes any legal liability or responsibility for the accuracy, completeness, or usefulness of any information, apparatus, product or process disclosed, or represents that its use would not infringe privately owned rights. Reference herein to any specific commercial product, process or service by trade name, trademark, manufacturer, or otherwise does not necessarily constitute or imply its endorsement, recommendation, or favoring by the United States Government or any agency thereof. The views and opinions of authors expressed herein do not necessarily state or reflect those of the United States Government or any agency thereof.

This report has been reproduced directly from the best available copy.

Available for sale to the public, in paper, from: U.S. Department of Commerce, National Technical Information Service, 5285 Port Royal Road, Springfield, VA 22161, phone: (800) 553-6847, fax: (703) 605-6900 email: orders@ntis.fedworld.gov online ordering: http://www.ntis.gov/ordering.htm

Available electronically at http://www.doe.gov/bridge Available for a processing fee to U.S. Department of Energy and its contractors, in paper, from: U.S. Department of Energy, Office of Scientific and Technical Information, P.O. Box 62, Oak Ridge, TN 37831-0062, phone: (865)576-8401, fax: (865) 576-5728 email: reportseadonis.osti.gov 


\section{DISCLAIMER}

Portions of this document may be illegible in electronic image products. Images are produced from the best available original document. 


\author{
BNFL Report, \\ Glass Formers Characterization
}

December 29, 1999

\author{
R.F. Schumacher, 773-43A \\ Savannah River Technology Center \\ Westinghouse Savannah River Company \\ Aiken, SC 29808
}

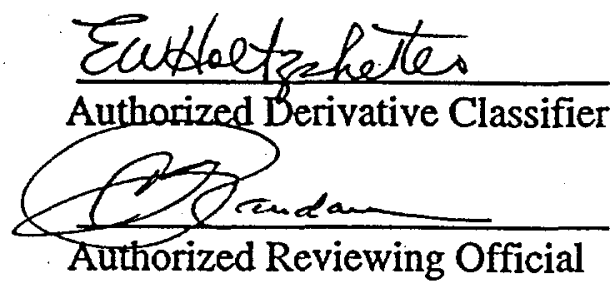

\title{
DISCLAIMER NOTICE
}

This report was prepared by Westinghouse Savannah River Company, Inc. (WSRC) on behalf of the U.S. Department of Energy (DOE), as an account of work sponsored by BNFL, Inc. Neither WSRC, DOE, the U.S. Government, or any person acting on their behalf makes any warranty, express or implied, or assumes any legal liability or responsibility for the accuracy, completeness, or usefulness of any information, apparatus, product, or process disclosed, or represents that its use would not infringe privately owned rights. Reference herein to any specific commercial product, process, or service by trade name, trademark, manufacturer, or otherwise, does not necessarily constitute or imply its endorsement, recommendation, or favoring by WSRC, DOE, or the U.S. Government. The views and opinions of authors expressed herein do not necessarily state or reflect those of WSRC, DOE, or the U.S. Government.

Savannah River Technology Center

Westinghouse Savannah River Company

Aiken, SC 29808 
TABLE OF CONTENTS

TABLE OF CONTENTS

Page No.

LIST OF TABLES AND FIGURES

SUMMARY

INTRODUCTION

EXPERIMENTAL

Powder Physical Properties

Chemical Properties

Powder Flow Properties

Glass Former Selection

RESULTS AND DISCUSSION

Physical Property Characterization of Glass Formers

19 and Blends

Chemical Properties of Glass Formers

Flow Properties of Glass Formers and Blends

CONCLUSIONS

FUTURE DEVELOPMENT

APPROVALS

REFERENCES

DISTRIBUTION

ATTACHED TABLES

APPENDIX A Particle Size Distribution $\quad \mathbf{4 0 - 4 1}$

APPENDIX B Handling Hazards of BNFL Glass Formers

$42-43$ 


\section{LIST OF TABLES AND FIGURES}

TABLES

Page Number

Table 1 Blend Identification from Vitreous State Laboratory

9

Table 2 Glass Formers Used to Prepare Blends

10

Table 3 Typical Johanson Indices for Common Materials

$14^{2}$

Table 4 Glass Formers Selected for Characterization

Table 5 Summary BNFL Glass Formers Physical Property Characterization

Table 6 Summary BNFL Glass Formers Durability in NaOH

Table 7 Glass Formers Containing Toxic or Radioactive Elements

Table 8 Typical Chemical Analysis as Supplied by Vendor

Table 9 Summary BNFL Glass Formers Flow Property Characterization

Figure 1 Johanson Arch Index 12

Figure 2 Johanson Flow Rate Index 13

Figure 3 Johanson Hopper Index 


\section{SUMMARY}

The objective of this task was to obtain powder property data on candidate glass former materials, sufficient to guide conceptual design and estimate the cost of glass former handling facilities as requested under Part Bl of BNFL Technical and Development Support. Twenty-nine glass forming materials were selected and obtained from vendors for the characterization of their physical properties, durability in caustic solution, and powder flow characteristics. A glass former was selected based on the characterization for each of the ten oxide classes required for Envelope A, B, and C mixtures. Three blends (A, B, \& C) were prepared based on formulations provided by Vitreous State Laboratory and evaluated with the same methods employed for the glass formers. The properties obtained are presented in a series of attached Tables. It was determined that five of the ten glass formers, (kyanite, iron oxide, titania, zircon, and zinc oxide) have the potential to cause some level of solids flow problems. In addition, all of the blends may require consideration for their handling.

A number of engineering considerations and recommendations were prepared based on the experimental findings, experience, and other process considerations. Recommendations for future testing are included. In conjunction with future work, it is recommended that a professional consultant be engaged to guide and assist with testing and design input.

\section{INTRODUCTION}

British Nuclear Fuels Ltd. (BNFL) contracted with the Savannah River Technology Center (SRTC) to supply technical information and engineering data to assist BNFL in estimating the cost and layout of the glass former feed system for the River Protection Project - Waste Treatment Plant (RPP-WTP) at the Hanford Site near Richland, Washington. The Vitrification Facility will employ three or more, Joule heated, glass melters with a total capacity approaching sixty tons per day. This proposed facility will vitrify Low Activity Waste (LAW) streams generated by the RPP-WTP Pretreatment Facility. A smaller but generally similar glass former system will be employed to prepare the glass former mixture for High Level Waste (HLW) vitrification in a two tons per day melter.

The glass former process layout has not been completely defined, at this time, but will involve the production of glass former feed from blends of approximately ten glass former minerals and / or chemicals [1]. A list of preferred glass formers was obtained from Vitreous State Laboratory (VSL). The blends of glass formers are then mixed with the treated liquid HLW and LAW streams and pumped to the electric melters for vitrification. The resulting vitreous waste form will be required to meet waste form acceptance criteria. This would require strict control and prediction of the composition of the waste form. Also BNFL has noted concerns about solids flow, mixing, segregation, and sampling of the blended glass formers in the handling system. 
Generally chemical processing plants, which involve the handling of powder streams, experience a high level of startup delays, process inefficiencies, and equipment downtime. This was confirmed by a six-year study of 40 solids processing plants in the U.S. and Canada [2]. The findings revealed that $80 \%$ of all the plants studied experienced solids handling problems. The affected facilities were slow in coming up to speed, with an average startup time for some of the plants approaching 18 months. Once startup began, poor performance continued to plague these operations with capacity limitation ranging between 40 to $50 \%$ of the design values. Although considerable engineering resources are usually allocated to processing concerns, design of the powder handling systems rarely get the level of effort required.

Solids flow problems may occur in a variety of solids processing equipment; however, the most common problems occur either in storage silos or during material transfer. The problems, that occur in silos and transfer lines may consist of the following:

- No-flow from a silo / hopper is the most common and often the most serious handling problem. This can be due to the formation of an "arch" (bridging) or a "rat hole" at the hopper opening. Arching occurs when the cohesive forces in the powder are greater than the downward pressure within the hopper. An arch develops over the hopper opening and flow is impeded. Rat holing occurs when the material flow takes place through a central channel in the silo/hopper that forms within the bulk of the material. If the powder has sufficient cohesive strength, after the channel has emptied, no more flow will occur. New material can fill the rat hole and this material will be used to continue feeding the process. This can lead to time induced degradation of the stagnant material and to poor utilization of silo capacity. The addition of vibration or other flow-aids to improve flow in silos often resultyin making the compaction problems worse.

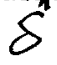

- Erratic flow is the result of flow obstructions alternating between an arch and a rat hole.

- Flooding / flushing can occur with fine powders such as pigments or precipitates. When a rat hole forms and then collapses, the falling particles entrain air and become fluidized. Since most solids-handling equipment is not designed for fluids, material may flood through the feeder outlet. Filled silos have been unintentionally emptied in this manner. The use of proper silo / hopper design should eliminate all of the above problems.

- Flow rate limitation is another problem unique to fine powders. Most fine powders have low air permeability and are affected by any movement of interstitial air. The pressure gradients caused as a result of this gas movement can retard the discharge rate from a hopper limiting the feed rate. Insertion of small amounts of additional air in strategic locations in the hopper can greatly reduce this problem.

- Particle segregation (de-mixing) can occur anytime a blend of materials is moved or handled. Simply filling and emptying a silo / hopper can greatly segregate portions of a blend. Segregation is largely caused by the significant difference in particle size of the components of the blend. Segregation within blends can be controlled by material selection and proper design of the storage and handling systems. 
- Structural failures in the silo / hopper can occur when large masses of material suddenly fall, as a result of collapsing arches or rat holes, and impact on the outlet of the silo and the feeder. In addition, silo walls can dent or wrinkle as a result of uneven loads imposed by asymmetric flow channels. [3]

As previously mentioned, these problems can be eliminated or controlled by the proper design of the storage silo / hoppers, feeders, and handling systems. The first step in proper design is to determine the characteristics of the individual glass formers and the blends of the glass formers. The original scope of work for this task, was based on material characterization and a cooperative program with a nationally known consultant in the area of solids flow. Two companies, (Jenike \& Johanson Inc. and J.R. JohansonDiamondback Technology Inc.) were under consideration when the scope of work was reduced. The scope was limited to the comparative characterization of select glass former candidates. This characterization included glass former physical, chemical, and solids flow properties. A final task plan was presented to BNFL [4], which described the determinations to be carried out and the necessary quality assurance controls to perform the tests.

\section{EXPERIMENTAL}

When dealing with powders, it is essential to handle the materials carefully and to obtain samples which are representative of the whole of the material. Representative samples were requested from the material vendors. When the samples were opened, a large portion of the material was obtained and the initial physical properties were measured from split samples. This material was split using a rotary riffler to reduce the material to $1 / 8$ th and then 1/64th samples as required. These samples were stored in sealed plastic containers. These split samples were then used to determine the physical properties. Large grab samples were used to measure both the Johanson flow indices and the durability in alkaline solutions. Balances were calibrated with a class 2 set of weights. All calibration measurements were maintained in a calibration logbook and data was recorded in a WSRC laboratory notebook. All tests were carried out using written procedures.

\section{Powder Physical Properties}

\section{Loss on Drying}

The Loss on Drying (LOD) provides a measurement of adsorbed moisture. The LOD was determined from two $1 / 64^{\text {th }}$ split samples which were placed in two small weighed porcelain crucibles, weighed again, and then placed in a drying oven at $110^{\circ} \mathrm{C} \pm 3^{\circ} \mathrm{C}$ for at least one hour. Upon removal from the oven the two crucibles were cooled in a desiccator for one hour and re-weighed. The Percent LOD was determined as follows:

$$
\% \text { LOD }=\frac{(\text { As Received Weight }- \text { Dried Weight }) \times 100}{\text { As Received Weight }} \quad \text { Equation } 1
$$


The reported value for LOD was the average of the two measured values.

\section{Loss on Ignition}

The Loss on Ignition (LOI) is a measurement of water, $\mathrm{CO} 2$, and other organics which are chemically bonded to the powder. The LOI was determined from two $1 / 64^{\text {th }}$ samples which were placed in two small pre-weighed porcelain crucibles, weighed again, and placed in an ignition furnace at $600^{\circ} \mathrm{C} \pm 10^{\circ} \mathrm{C}$ for one hour. Upon removal of the crucibles from the furnace, the crucibles were cooled in a desiccator for one hour and re-weighed.

The Percent Loss on Ignition was determined as follows:

$$
\% \text { LOI }=100 \times \frac{\text { As received Weight }- \text { Ignited Weight }}{\text { As Received Weight }} \quad \text { Equation } 2
$$

The reported value for LOI was the average of the two measured values.

\section{Powder Densities}

Powder densities are used to determine silo capacity and as a basis for other powder flow or capacity determinations. The powder densities determined in this study were "As Received", "Packed", and "True Particle" density. The densities will be explained in the following paragraphs.

Two to four $1 / 8^{\text {th }}$ samples (approximately $100 \mathrm{cc}$ of material) were placed in a weighed $250 \mathrm{cc}$ graduated cylinder. The material was repeatedly turned top to bottom to disperse and aereate the material. *The volume of the material was recorded after sitting for a few minutes. All of the materials in this investigation appeared to go from fluidized to a deaereated state very quickly. This observation might not hold if larger quantities of the materials are deaerated and the settling times are increased. The graduated cylinder was then weighed. The "As Received" Bulk Density was determined using the following formula:

\section{As Received Bulk Density $(\mathrm{g} / \mathrm{cc})=$ Material Weight $/$ Dispersed Volume Eq. 3}

The graduate cylinder containing the material was then placed on the Quanta Chrome Autotap instrument and set for 2000 taps. This system is similar to the system specified for the ASTM B527 for the tap density of metallic powders. At the completion of the test the tapped volume in the graduated cylinder was determined and the Packed Bulk Density was calculated using the following formula:

$$
\text { Packed Bulk Density }(\mathrm{g} / \mathrm{cc})=\text { Material Weight } / \text { Packed Volume Equation } 4
$$

Approximately $50 \mathrm{cc}$ of the packed material was then used to determine the True Particle Density. A Quantachrome ${ }^{\text {TM }}$ Stereopycnometer system, which relies on pressure-volume 
A stainless steel sphere of known volume $(56.559 \mathrm{cc})$ was used to calibrate the unit before each day of operation. The difference between the actual and measured volume for the sphere was always less than $0.2 \mathrm{cc}$. The reported True Particle Volume was the average of three volume measurements. The True Particle Volume was obtained using the following equation for this instrument:

$$
\text { True Particle Volume }=153.589+79.271 /(1-\mathrm{P} 2 / \mathrm{P} 3), \quad \text { Equation } 5
$$

where P2 and P3 were measured values obtained from the pressure transducer read-out. The True Particle Density was then obtained by dividing the gravimetric weight of the powder by its measured true particle volume. The True Particle Density is related to the buoyancy force on the particles when the powder is placed in a liquid.

\section{Particle Size Distribution}

Initially an ATM Ultrasonic Sifter was used with appropriate micro sieves to determine the particle size distribution of the glass formers. This procedure agreed well with the vendor data for the granular powders but was not found to be acceptable for powders with large fractions below 325 mesh ( 44 microns). One of the dry samples used to measure the LOD was used for the test. Sample size was always less than 10 grams.

Later, some of the important pigment grade materials were submitted to the Analytical Development Section for the determination of particle sized distribution in volume \% less than - microns. The instrument employed was a Microtrac - SRA150. The fluids used in these tests were water and a dispersing agent, which acted to break up the agglomerates.

\section{Preparation of Blends}

Blends of glass formers were prepared from spreadsheet calculations supplied by VSL. Table 1 provides the details used to calculate the composition of the blend.

Table 1. Blend Identification from Vitreous State Laboratory

\begin{tabular}{lll} 
Envelope & Moles of Sodium & Identity of Blend \\
\hline Envelope A & 10 Molar Sodium & LAWA44-AN105 \\
Envelope B & 5 Molar Sodium & LAW B29-AZ101 \\
Envelope C & 8 Molar Sodium & LAWC12F
\end{tabular}

Every effort was made to come as close as possible to the materials selected by VSL, however, slightly different materials were selected for the zinc oxide, zircon flour, iron oxide, and titania. These commercial glass formers were used because VSL had not, at that time, specified a commercially available, technical grade for these oxides. Weighing was carried out on calibrated balances according to written procedure. Mixing of the blends was by shaking in a two liter container for ten minutes. 
Table 2. Glass Formers used to Prepare Blends

\begin{tabular}{|c|c|c|}
\hline Glass Formers: & (Grade) & Vendor Company, Location \\
\hline Kyanite-Raw & $(-325$ mesh $)$ & Kyanite Mining Corp., Dillwyn, VA \\
\hline Boric Acid & (Technical Grade) & U.S. Borax, Valencia, CA \\
\hline Wollastonite & (NYAD-325 mesh) & NYCO Minerals, Lewis, NY \\
\hline Iron Oxide & (Fe2O3 Hematite) & $\begin{array}{l}\text { Industrial. Metals, E\&B Inc. } \\
\text { Houston, TX }\end{array}$ \\
\hline Lithium Carbonate & (Technical Crystal) & $\begin{array}{l}\text { Cyprus-Foote, King's Mt, NC } \\
\text { (Chemetall-Foote) }\end{array}$ \\
\hline Olivine & (325 mesh \#180) & Unimin Co., Hamilton, WA \\
\hline Silica & (SCS-No. 75) & U.S. Silica, Mill Creek, OK \\
\hline Titania & $(1000)$ & Kronos, Houston, TX \\
\hline Zinc Oxide & (Densox-730) & Eagle Zinc Co., Hillsboro, $\mathrm{IL}$ \\
\hline Zircon & on Flour 325 mesh) & Elf Atochem, Andrews, SC \\
\hline
\end{tabular}

\section{Chemical Properties}

\section{Chemical Analysis}

The chemical analysis provided by the vendors was judged to be sufficient for most aspects of this initial task. Some of the glass formers contained traces of RCRA hazardous metals and it was decided to check the amounts. Select glass formers were sent to the SRTC Mobile Laboratory for chemical analyses of the trace toxic elements.

\section{Durability}

Small volume samples of the powders, $0.5 \mathrm{cc}$, were placed in $25 \mathrm{ml}$ of water or sodium hydroxide solution and held for 24 hours at room temperature and at $50^{\circ} \mathrm{C}$. The samples were then vacuum filtered using a written procedure. The filter paper was Durapore ${ }^{\mathrm{TM}}$ 0.45 micron. The filter appeared to capture all of the powder and the filtrate was clear. The filtered materials were dried at $110^{\circ} \mathrm{C} \pm 3^{\circ} \mathrm{C}$ for one hour to remove adsorbed water and weighed. The percent weight loss in percent was used as an indirect measure of the material durability. It was possible that some minerals may have formed some stable hydrates and could have both lost and gained weight in this manner. No account was taken for any weight gain due to possible hydrate formation and this may have influenced the results to smaller weight loss.

\section{Powder Flow Properties}

\section{Static Angle of Repose}

When an unconsolidated bulk solid is carefully deposited from a fixed height on a horizontal surface to form a pile, the particles of the solid roll down the pile and the slope of the pile forms an angle of repose with the horizontal plane. 
While the utility of the information available from this type of measurement is limited, this test is so simple, it was the first flow property measured for each sample. The measurement was made by pouring some of the powder through a funnel onto a pile in a stainless steel pan. The angle of the pile was measured from the horizontal with a gravity angle-protractor. For a very flowable powder, the angle will be low. If the forces acting between particles are significant in comparison with the force of gravity (cohesive powder) the angle of repose will be high. This measurement is also useful in helping to determine the actual material capacity of a particular silo. An approximation of the cone of material at the top of the silo may be obtained from the angle of repose.

\section{Johanson $^{\mathrm{TM}}$ Arching Index}

The three Johanson ${ }^{\mathrm{TM}}$ Indicizers were used as scoping tools to evaluate the glass former powders for material handling problems. The Johanson instruments are operated by internal computer controls which reduce many operator associated errors. The computer calculates the index values based on the hypothetical hopper dimensions entered into the computer. All of the measurements were made based on a hypothetical, cylindrical silo ( $10 \mathrm{ft}$. Dia.) with a simple conical bottom and a hopper slope angle of $20^{\circ}$ from vertical. This is the standard silo used by J.R. Johanson for comparative purposes. This is a very steep angle and practically guarantees mass flow of the material from the silo. Mass flow is defined as movement of all particles within a silo / hopper at the same moment. This is a major improvement over funnel flow which can lead to hang-ups and rat holes in the hopper. The silo opening used for the calculations was one foot in diameter [5].

The Johanson ${ }^{\mathrm{TM}}$ Hang-up Indicizer is a uniaxial powder shear tester and can be used to determine the "Arching Index" or "Rat hole Index". The Arching Index (AI) provides a direct measure of the minimum circular opening ( $\mathrm{ft}$.) which will not bridge from the previously specified conical hopper. The stainless steel cell with a movable bottom is first weighed and filled with the powder, about $2 / 3$ full. See Figure 1 for a simple schematic of the active parts.

The cell is re-weighed to determine the weight of the powder. The cell is then inserted into the Indicizer and the test information entered. The test than automatically presses the powder to form a bridge between the upper and lower pistons. The pressure applied is the expected outlet pressure or about 1.5 foot of head of solids for a $10 \mathrm{ft}$. diameter bin. The Indicizer then removes the bottom and upper pistons. The upper-internal piston connected to a load cell then fails the bridge and measures the required force. The Indicizer interprets the results as the critical outlet size to prevent arching. This test was usually repeated three times and averaged.

If a bridge could not be formed in the cell, an Indicizer opening of $<0.2 \mathrm{ft}$. was given by the computer as the answer and the test was usually not repeated. The same Indicizer can also be used to obtain the Rat hole Index (RI), which is the critical channel rat hole diameter. 


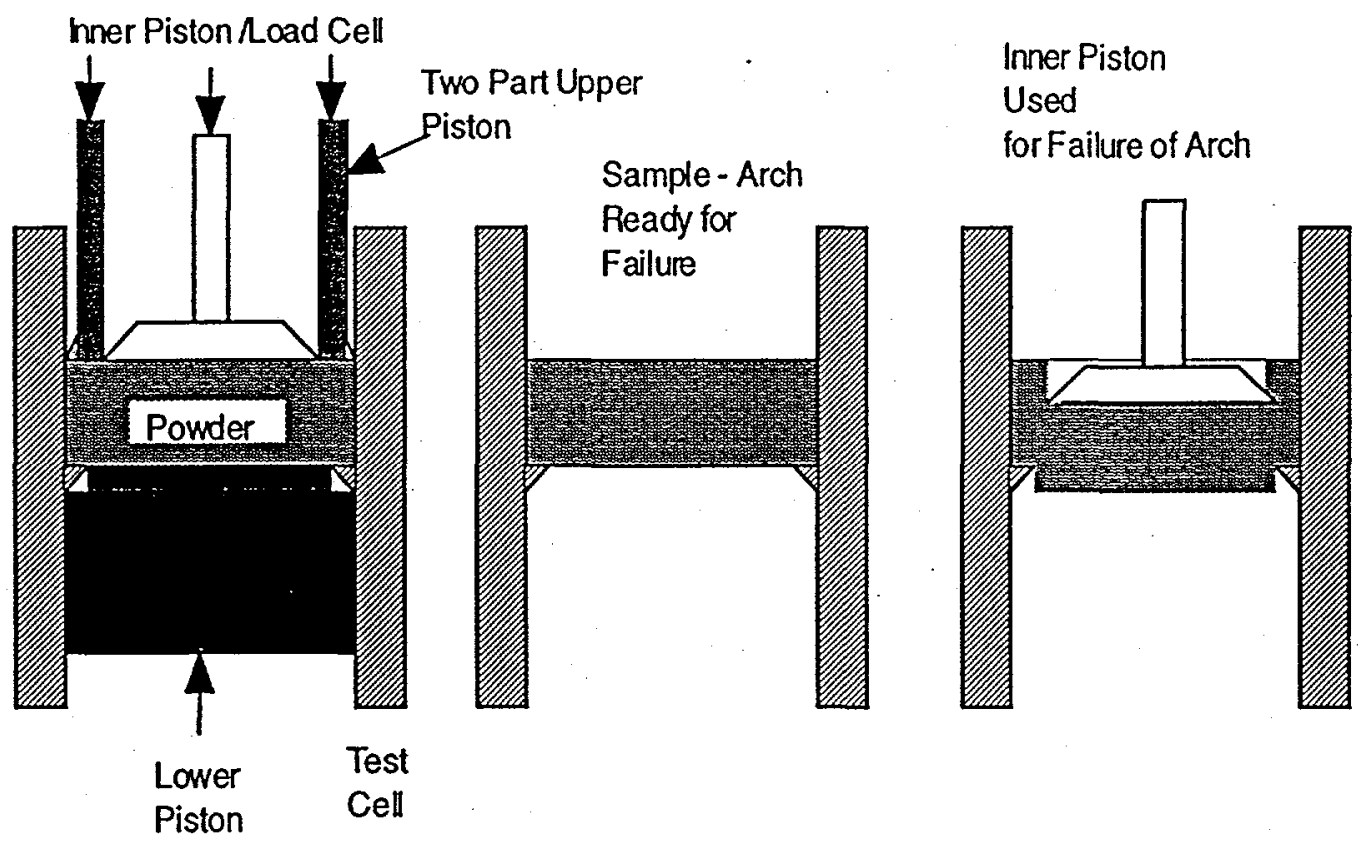

Figure 1 Johanson Arch Index

\section{Johanson $^{\text {TM }}$ Flow Rate Index}

The Johanson ${ }^{\mathrm{TM}}$ Flow Rate Indicizer (FRI) is a gas permeability test which calculates the material flow rate for deaerated material through a 12 inch diameter outlet. The maximum flow rate without air injection for other hopper designs is obtained by multiplying the FRI index by the ratio of the outlet area to a one foot diameter circle. This is true, provided the outlet diameter exceeds the arching index AI. The standard test also measures the bulk density at the outlet of the hopper (Feeder Density Index - FDI) and the maximum density expected in the hopper (Bin Density Index - BDD). After the bin density is measured, the tester slowly raises the top piston and determines the percentage of material springback (Springback Index - SBI). This is important for highly resilient materials, e.g. wood chips, etc. An SBI less than 3.0 percent was not considered significant. See Figure 2 for a schematic representation of the test cell.

In calibrating this unit with the standard reference material supplied by J.R. Johanson, Inc., an unusually large correction factor of $1 / 210$ was necessary to bring the values into line with the given data. This brings the data obtained with this particular Indicizer into some question. While this measurement was found to be consistent, it is probable there was some type of mechanical or computer problem with the apparatus. The FRI data, presented in this report, was divided by a factor of 210 . The values thus obtained appeared to be within reason for known materials. However, the values should be confirmed prior to use for design purposes. 


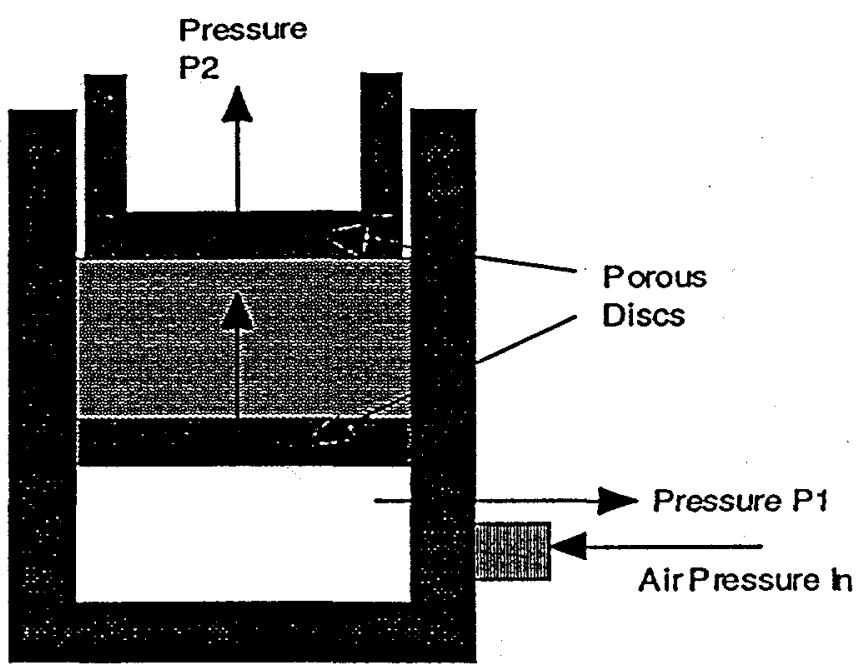

\section{Figure 2. Johanson Flow Rate Index}

\section{Johanson ${ }^{\mathrm{TM}}$ Hopper Index}

This Indicizer calculates the Johanson ${ }^{\mathrm{TM}}$ Hopper Index (HI) by measuring the surface friction at two predetermined compaction pressure levels and interpolating to the conditions at the outlet. This data is then used to calculate the hopper angle required to initiate movement along the walls of a conical hopper. The computer calculation included a four degree safety margin within the obtained value. The calculated angle, measured from the vertical, is the Hopper Index (HI). The metal surface employed in all of these tests was 304-2B stainless steel. Additional materials, e.g. rusty carbon steel and epoxy were also available for testing. A Chute Index (CD) could also be determined with this equipment and this index recommends the chute angle necessary to prevent material build up on the solids impact areas.

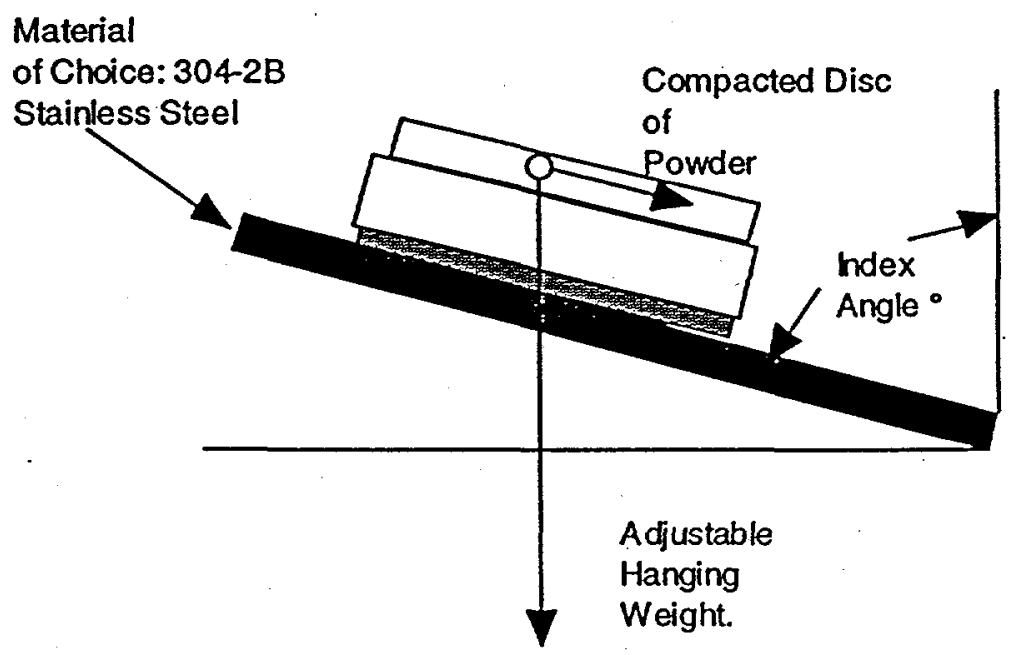

Figure 3 Johanson Hopper Index 
Conical hoppers can be designed using the Indicizers. $\mathrm{HI}$ is the angle from the vertical for flow at the hopper walls. AI is the minimum outlet diameter. FRI is the maximum flow rate for a 12 inch outlet and may be increased by air injection. The conical hopper is very appealing because of its simplicity in visualization and construction. However, other hopper shapes may be much better in certain instances, e.g. limited head-space, etc. The indices can be extrapolated to these other hopper shapes using Johanson guidelines. It should be repeated that these initial tests should only be used to identify the problem materials.

\section{Typical Johanson $^{\mathrm{TM}}$ Indices for Common Materials}

Table 3, presents a comparison of the Johanson ${ }^{\mathrm{TM}}$ Indices measured for some common materials. These measurements are based on a standard conical mass flow silo with a diameter of 10 feet, an outlet diameter of 12 inches and a slope of $20^{\circ}$ from vertical. The abbreviations were explained previously.

Table 3. Typical Johanson ${ }^{\mathrm{TM}}$ Indices for Common Materials

$\begin{array}{lllllllll}\text { Material } & \text { AI } & \text { RI } & \text { FRI } & \text { FDI } & \text { BDI } & \text { SBI } & \text { HI } & \text { CI } \\ \text { Boric Acid } & & & & & & & & \\ \text { Brown Sugar } & 1.4 & 2.5 & 195 & 55.8 & 60.3 & 1.5 & 26 & 40 \\ \text { Cleanser Powder } & 0.3 & 1.2 & 4479 & 41.9 & 57.9 & 1.1 & 1.7 & 66 \\ \text { Corn Meal } & <0.2 & <0.3 & 4123 & 41.7 & 77.7 & 0.7 & 13 & 50.5 \\ \text { Granulated Sugar } & <0.2 & <0.3 & 10033 & 53.2 & 54.1 & 0.5 & 20 & 23 \\ \text { Portland Cement } & 1.0 & 5.3 & 15 & 72.1 & 93.7 & 2.2 & 15 & 37 \\ \text { Salt Iodized } & <0.2 & <0.3 & 4123 & 41.7 & 45.5 & 1.0 & 33 & 23\end{array}$

The indices presented are for comparative purposes only and were supplied by J.R. Johanson, Inc., with their Johanson ${ }^{\text {TM }}$ Indicizer information.

\section{Glass Former Selection}

For a particular glass composition, there are a very large number of glass forming materials which may be selected to prepare the glass recipe. For example, a glass frit is a major component for the high level waste glass produced at the Savannah River Site Defense Waste Processing Facility (SRS-DWPF). The frit is relatively expensive compared to glass forming materials but provides a strong advantage for process control and waste acceptance. The West Valley Treatment Facility, on the other hand, employed raw chemicals to prepare their waste glass. The chemical approach reduces manufacturing cost and permits rapid change in the waste glass formulation. BNFL has selected the use of a combination of natural minerals and chemicals for their glass vitrification facility. 
A primary criteria for the initial glass former selection was low sodium level in the materials since the waste streams already contain a very high percentage of this element. For this investigation, a selection of initial candidates was made jointly by Vitreous State Laboratory (VSL) and the Savannah River Technology Center (SRTC). The following additional criteria were used to select the candidates for this preliminary study:

Oxide composition - including oxide consistency, trace elements, e.g. $\mathrm{Na} 2 \mathrm{O}$ etc, Minimize volatile components such as carbonates, chemical water, etc., Minimize transportation costs and insure availability, Bulk physical properties, Material flow properties and Dispersion and durability in $\mathrm{NaOH}$ solutions.

Based on these selection criteria, twenty-nine glass formers were selected. The glass formers are listed in Table 4 and attached at the end of this report. The materials have been divided into categories based on their major contribution to the glass forming recipe. The list is representative of the type of materials available for use.

\section{Alumina (Al2O3) Containing Glass Formers}

Alumina containing glass formers suitable for the vitirification of radioactive waste streams at the Hanford River Protection Project can range from the high purity and high cost alumina materials developed for the fine ceramics industry to raw mineral products for the industrial ceramics industry. Examples of the raw minerals are kyanite (3Al2O33SiO2), mullite (3Al2O3-2SiO2), feldspars (e.g. $\mathrm{R} 2 \mathrm{O}-\mathrm{Al} 2 \mathrm{O} 3-6 \mathrm{SiO} 2$, etc.) and clays (Al2O3-2SiO2-2H2O). Normally alumina is not a major component in glass but is sometimes added at up to $16 \mathrm{wt} \%$ in glass fiber and up to $30 \mathrm{wt} \%$ in certain boroaluminosilicate glasses. Most soda-lime (window) glass contains one to three wt\% alumina. Alumina in general tends to increase the viscosity, inhibit devitrification, improve chemical durability and may alter other characteristics of the glass.

Calcined Alumina (A12O3): These materials are available in a wide variety of purity and grade. Generally they contain at least $99 \% \mathrm{Al} 2 \mathrm{O} 3$ and are available from 10 micron down to sub-micron particle size. The alumina is obtained from bauxite ore by purification. The calcined alumina is more difficult to melt than many other minerals and is used in glasses where there is a requirement to limit the iron and titanium content.

Kyanite (Al2O3-3SiO2): This is a natural mineral mined from areas in Virginia and is available from several hundred micron to below 44 micron. The alumina content is variable and may range between 54 to $60 \mathrm{wt} \%$, while the silica content varies between 43 to $38 \mathrm{wt} \%$. This material can be pre-fired to alter the thermal expansion characteristics and is then labeled as mullite or calcined kyanite. Similar minerals, andalusite and sillimanite, are often employed in the production of high alumina refractories. 
Feldspars (R2O/RO-Al2O3-6SiO2): While various aluminosilicates can be used for the waste glass, care must be taken to select materials with low $\mathrm{Na2O}$ levels to meet the primary criteria. Many of the feldspars contain high $\mathrm{Na} 2 \mathrm{O}$ levels.

Clays (A12O3-2SiO2-2H2O): Clays are formed during the geologic weathering of the feldspars. Kaolin clay, for example, is used as a source of alumina for the production of continuous glass fiber products. The clay is quite fine (less than 1 micron) and changes the viscosity of a slurry. Other clay like materials can be used to intentionally alter the viscosity of slurries. Commercial quantities of pre-fired clay (grog) are also available at additional cost. The grog, when ground, would be similar in composition and character to the kyanite materials.

\section{Boron Oxide (B2O3) Containing Glass Formers}

Boron in glass tends to lower the liquidus temperature and viscosity of many glasses. Boron does not reduce the durability to the same extent as the alkalis. Boron may be introduced either as a processed chemical or as a natural mineral. The most common boron chemicals used in glass making are pentahydrate borax (Na2B4O7.5H2O), boric acid (H3BO3), and anhydrous borax (Na2B4O7). In the United States these chemicals are produced in California near Death Valley. Two other mineral forms are ulexite (sodium calcium borate) and colemanite (calcium borate).

The country, Turkey, is the source of most boron minerals but lesser amounts may be obtained from Chile, Argentina and Russia. Some of the boron minerals were eliminated by their $\mathrm{Na} 2 \mathrm{O}$ content.

\section{Calcia (CaO) Containing Glass Formers}

Limestones ( $\mathrm{CaCO} 3$ or $\mathrm{Ca}, \mathrm{MgCO} 3$ ): Calcia sharply reduces glass viscosity and does not reduce the durability to the same extent as alkali. Most glass manufacturers use various grades of limestone $(\mathrm{CaCO} 3)$ or dolomite $(\mathrm{Ca}, \mathrm{MgCO} 3)$ as the principle source of calcia. This is a very low cost material and is widely available. The carbonates were described as a problem for the Hanford Process. A calcined dolomite (commonly called glass lime) is also available but this material is not as stable and can combine with water and $\mathrm{CO} 2$ from the air.

Feldspars (CaO-Al2O3-nSiO2): These are mineral alternatives to limestones and may be obtained as aplite or anorthite, which are calcium aluminosilicates.

Wollastonite (CaO-SiO2): The mineral calcium silicate (wollastonite) is used as a filler in resin materials or in ceramics as a glaze component and in certain whiteware bodies. This material is mined, crushed and classified to specificatons. The crystal shape is acicular (needle like). The mineral is presently mined in New York State and in the Sonoran area of Mexico 


\section{Magnesia (MgO) Containing Glass Formers}

Magnesia, as was previously mentioned, is normally introduced as dolomitic limestone, but since there is a need to avoid carbonates, other materials must be considered.

Olivine (Mg2,FeSiO4): This is a mineral which is available in the American Northwest. This mineral is used in certain refractory materials. Grades from granular to 325 mesh are available. Olivine is mined, ground, and classified.

Magnesite (MgO): This is a high purity chemical obtained from the processing of salts obtained from the sea. It can be obtained as $99 \%$ pure $\mathrm{MgO}$.

Talc and other hydrates (MgO-SiO2-H2O): These minerals are also mined in New York State and are available in various grades. They are used in various whiteware bodies and to produce ceramic glaze slips. Some colloidal magnesium aluminum silicates can be used to intentionally modify the viscosity of liquid slurries.

\section{Iron Oxide (Fe2O3) Containing Glass Formers}

The glass makers natural intent is to limit the presence of iron oxide in the glass in order to maintain transparency. Iron oxide can color the glass green, blue, or brown depending on the oxidation state of the iron and the basic glass composition. Iron oxide is present in many radioactive waste glasses because it is either already present in the waste or added to reduce the viscosity of the glass. The presence of iron oxide also improves the solubility of some waste components and is not as deleterious to the glass durability as alkali.

Ferric Oxide ( $\mathrm{Fe} 2 \mathrm{O} 3$ ): When iron oxide is required it may be introduced as red iron oxide (rouge), which is prepared by the calcining of ferrous sulfate to $\mathrm{Fe} 2 \mathrm{O} 3$. This material was an important polishing material for the manufacture of plate glass before the development of the float glass process. A mineral form of $\mathrm{Fe} 2 \mathrm{O} 3$ can also be obtained by crushing and grinding the iron ore, hematite.

Magnetite ( $\mathrm{Fe} 3 \mathrm{O} 4)$ : This material is obtained by crushing and grinding the mineral magnetite. The fact that it is partially reduced could be an advantage in lowering the amount of reducing agent required in some of the waste slurries.

\section{Silica (SiO2) Containing Glass Formers}

Silica is the most important constituent in commercial glasses because it is the primary glass-forming oxide. Silica provides much of the durability of the glass but also increases the glass viscosity. Silica sand is one of the more refractory batch materials and is slow to go into solution in the glass melt. Fine grain sand is said to improve the melting and homogeneity of the glass. 
Quartz (SiO2): Quartz is the most widely distributed single mineral on earth. A chief source of quartz in the eastern states is the Oriskany quartzite deposits occuurring in Pennsylvania and West Virginia [6]. This is a hard quartzite or sandstone. Other deposits are St. Peter sandstone occurring in the Fox River and Rock River Valleys of Illinois, in eastern Missouri, and in Oklahoma. These deposits are less firmly consolidated sandstones that apparently are of wind-blown origin and are easier to obtain and process. Many other deposits are scattered over the country, but may be less pure and containing other minerals. Certain deposits are available in a wide range of grain size while others have only a few grades available.

\section{Titania (TiO2) Containing Glass Formers}

Titania is introduced into glass to increase the refractive index or density of the glass or to lower the melting point of the glass while maintaining durability.

Titania (TiO2): This material is refined from rutile and ilmenite ores by chlorination. It is marketed as a fine white powder, finding extensive use in paints and the paper industry. Titania gives opacity to enamels and glazes. It is also added to raise the refractive index of glass. The titania is commercially available in many grades and is generally available as the rutile crystalline phase.

Ilmenite ore (FeTiO3): This ore has the chemical is associated with magnetite, hematite, or with weathered sands. Since both iron oxide and titania are required for most of the BNFL glass former formulations it may be possible to use one of the titania ores, ilmanite, directly if the composition is determined to be consistent.

\section{Zinc Oxide (ZnO) Containing Glass Formers}

Zinc Oxide $(\mathrm{ZnO})$ : This chemical is produced by direct oxidation of zinc metal. Its use in glass is limited due to its refractory nature and its tendency to increase the melting temperature of the glass. It is frequently found as a component in chemically resistant specialty glasses.

\section{Zirconia ( $\mathrm{ZrO2}$ ) Containing Glass Formers}

This material may be introduced as pure zirconium oxide or as the silicate mineral zircon. Zircon sands are mined in various regions along the Atlantic Coast.

Zircon ( $\mathrm{ZrSiO} 4)$ : This mineral additive to glass tends to increase viscosity, refractive index and resistance to weathering. It is a very dense and refractory material in glass. A fine grade is usually selected to improve dissolution and to avoid settling to the bottom of the melt or waste slurry. 


\section{Lithia (Li20) Containing Glass Formers}

Lithia (Li2O): This oxide may be introduced into glass as the processed chemical lithium carbonate (Li2CO3) or in the mineral forms spodumene ( $\mathrm{Li2O}$.A12O3.4SiO2), petalite $\mathrm{Li} 2 \mathrm{O} . \mathrm{Al} 2 \mathrm{O} 3.8 \mathrm{SiO} 2)$, or other forms. Lithia reduces viscosity but does not reduce the durability of the glass as much as other alkali elements. Its use in the commercial glass industry is limited by its very high cost.

\section{RESULTS AND DISCUSSION}

\section{Physical Property Characterization of Glass Formers and Blends}

The common physical properties, as described in the experimental section, for the twenty nine candidate glass formers were measured. Table 5 attached at the end of this report, presents a summary of the data obtained for these materials. The data obtained agreed well with the limited data supplied by the vendors in the technical data sheets. This physical property data was required for a number of the flow property characterizations. Specific comparisons showed that the true particle density of these materials varied from a low of 1.5 to a high of $5.2 \mathrm{~g} / \mathrm{cc}$. The boric acid is the least dense material and the zinc oxide is the most dense. The other densities (as received and packed) are related to the true density, the particle size distribution, and the intergranular properties of the materials. The particle size distribution ranged from 850 microns to less than 5 microns (at least two orders of magnitude). This wide variation in particle size is the major contributor to the segregation of chemical species in the blends of glass formers. Appendix A presents the particle size distributions obtained for some of the glass formers. The weight loss after drying and ignition was found to be low for most of the materials except the boric acid which contained hydrated water (H3BO3).

\section{Chemical Properties of Glass Formers and Blends}

The chemical properties determined were the solubility in water and in sodium hydroxide solutions (1 to 3 molar). During these tests, the material sample normally lost 2 to 4 percent of its weight due to handling during the filtering and drying steps. This level of weight loss was accepted as normal experimental error. Also it was possible that some amount of mineral hydrate may have formed on the surface of the materials, which would not necessarily be removed by the drying step at $103^{\circ} \mathrm{C}$. The data for these tests is presented as Table 6 at the end of this report. The following materials lost more than expected due to handling error:

$\begin{array}{ll}\text { Boric Acid } & >98 \mathrm{wt} \% \text { in water } \\ \text { Lithium Carbonate } & 58 \mathrm{wt} \% \text { in 3 Mole NaOH } \\ \text { Iron Oxide } & 10 \mathrm{wt} \% \text { in } 3 \mathrm{Mole} \mathrm{NaOH} . \\ \text { Zinc Oxide } & 7 \text { to } 10 \mathrm{wt} \% \text { in } 3 \mathrm{Mole} \mathrm{NaOH} \\ \text { Spodumene } & 7 \text { to } 10 \mathrm{wt} \% \text { in } 3 \mathrm{Mole} \mathrm{NaOH}\end{array}$


All the other glass formers lost weight within the normal experimental error limits of 4 wt\%. The blends were not tested.

A number of the glass formers suspected of containing trace amounts of toxic elements or radioactive elements were analyzed chemically and the data are presented as follows in Table 7. For other general purposes the vendor supplied "typical chemical analysis" was employed and this data is summarized in Table 8 at the end of this report. Appendix B presents any special handling steps required when working with these glass formers.

TABLE 7 Glass Formers Containing Toxic or Radioactive Elements

\begin{tabular}{lll} 
No & Glass Former & Toxic Elements (element wt\%) \\
\hline 5 & Raw Kyanite & None Detected \\
$\# 7$ & Florida Zircon & Uranium $<1.00$, Thorium $<1.00$ \\
$\# 9$ & Titania 3020 & Chrome $<0.03$ \\
$\# 14$ & Zinc Oxide & Lead $<0.2$, Cadmium $<0.02$ \\
$\# 16$ & Olivine & Chrome 0.36, Nickel 0.25 \\
$\# 18$ & Spodumene & None Detected \\
$\# 21$ & Wollastonite & None Detected \\
$\# 24$ & Silica OK & None Detected \\
$\# 26$ & Silica CA & None Detected \\
$\# 27$ & Silica ID & None Detected \\
$\# 28$ & Hematite & None Detected \\
$\# 29$ & Magnetite & Chrome $<0.03$
\end{tabular}

\section{Flow Properties of Glass Formers and Blends}

The data obtained using the Johanson ${ }^{\mathrm{TM}}$ Indicizers is presented at the end of this report in Table 9. Also included in this table are the measured angles of repose and the as received densities from Table 5 for comparison. Interpretation of this data is complex [5] but every effort will be made to explain the determinations for the simple conical hopper and the chisel hopper. See Figure 4 for a schematic comparison of these two simple designs.

The Arching Index (AI) distance is the minimum opening in the standard silo with conical hopper (see experimental section) where arching or hang-ups will not occur. The measured arching index varied from less than 0.2 feet for the more granular materials, coarse sands, etc. to almost 2.0 feet for the very fine pigment materials (Kronos 1000 and Cerox 506).

A two foot diameter opening would be very large for a conical hopper, but could be altered to a slot one foot wide and five feet long if the chisel type hopper were selected. Other more complex hopper designs, e.g. cone in cone, etc. could also be utilized as well.

The Feed Rate Index (FRI) as measured was adjusted by dividing the measured FRI by 210. This provided values similar to the data provided for the Johanson Standard material. As stated previously the FRI provides a measure of deaereated material flow through a 12 inch diameter opening in a conical mass flow hopper. 
This value can be adjusted to other designs outlets by factoring with the area ratio provided the outlet exceeds AI. If the required flow rate exceeds the adjusted FRI, air injection may be required. The adjusted values ranged between 168 pounds per minute for the boric acid to over 1000 pounds per minute for the red iron oxide. The FRI appears to correlate directly to the finer particle size materials. This result may be realistic based on flow from a conical mass flow hopper with a 12 inch diameter opening. The density values obtained for the materials appear to agree well with the as received density measured previously.
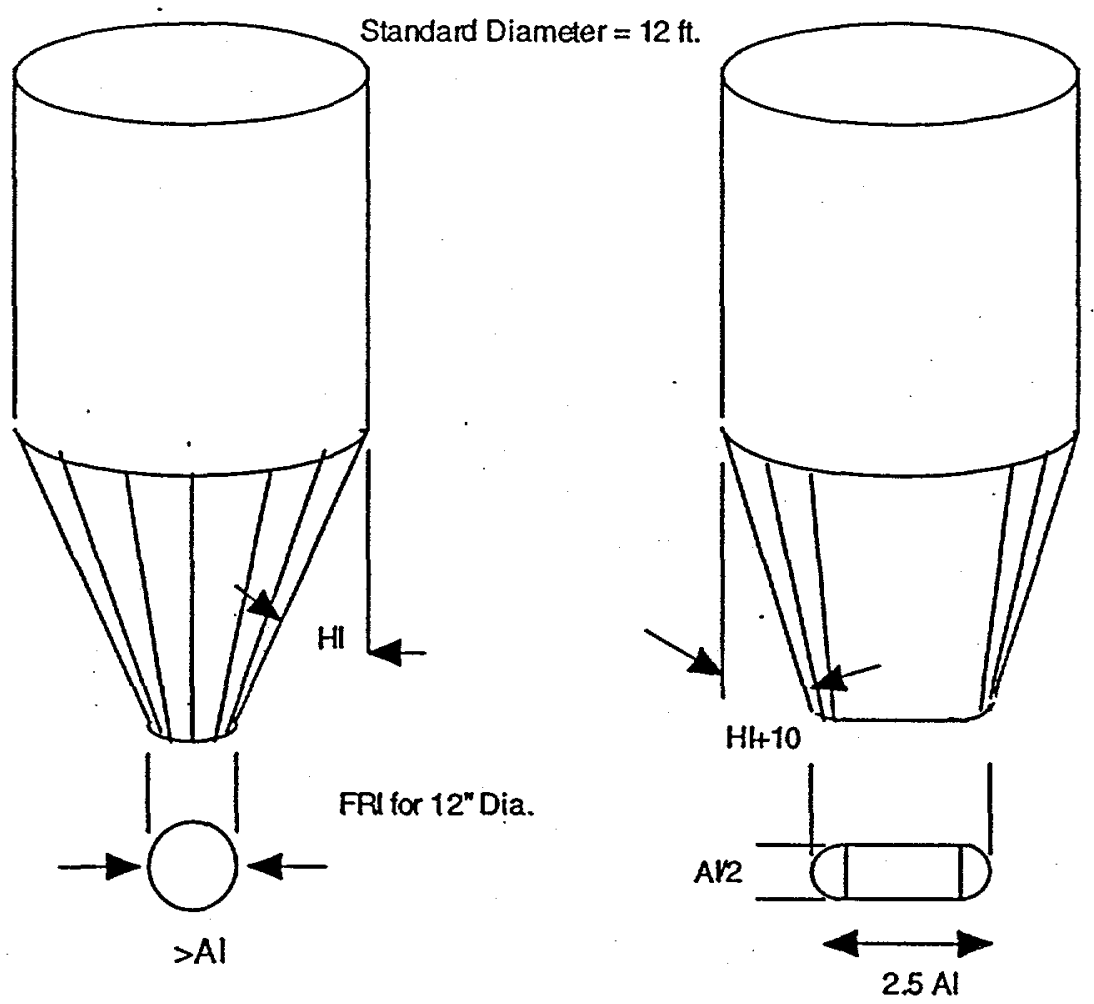

\section{FIGURE 4 SIMPLIFIED SCHEMATIC OF CONICAL AND CHISEL HOPPERS}

The values obtained for the Spring Back Index (SBI) were all below the 3 percent critical value. Values above 3 percent can indicate flow problems for compressible materials such as wood shavings, etc.

The Johanson ${ }^{T M}$ Hopper Index $(\mathrm{HI})$ was determined against 304-2B stainless steel and ranged between 5 to 20 degrees. The 5 degree value was obtained for the Kronos 1000 titania. This low value and indicated excessive friction between the materials and suggests the need for special hopper design considerations to prevent flow problems. The 20 degree value was obtained with the boric acid indicating good material flow. 
The angle of repose provides a measure of the cohesive forces within the powder and an estimate for calculating the complete capacity of a given silo. The final fill area of the silo should be approximated by the angle of repose.

The angle of repose was highest ( 50 degrees) for the fine alumina and kyanite and in the low 30's for boric acid, olivine, spodumene, and lithium carbonate. Some of the coarse silica sands also fell into this range.

The following describes the special observations for each of the blends and the ten glass former classes tested in this study:

Blends: The blends for envelopes A, B, and C were characterized and found to have marginal flow properties. The blend for the $B$ envelope clumped together after storage for thirty days in a sealed container. Additional testing should be carried out. Since the blends contain a portion of natural quartz, precautions against inhalation must be taken when handling (see silica).

Alumina: The selected glass former for alumina is raw kyanite from Kyanite Mining, Dillwyn, Virginia. There may be some silo-flow problems with this material. The ratio of $\mathrm{Al} 2 \mathrm{O} 3$ to $\mathrm{SiO} 2$ is somewhat variable and may make it difficult to predict the final chemical composition for the glass. An alternative to kyanite would be a calcined alumina, such as A-2 alumina from Alcoa Industries Bauxite, Arkansas. There may be some free silica in these materials.

Boron: Boric Acid from U.S. Borax, Valencia, California, appears to be the primary source of the boron glass former. It is relatively close to Hanford and is the accepted source for most boron products in the United States. The large particle size is required for product stability but would be a driving force for blend segregation. Should an alternate be required a colemanite mineral product might be considered.

Calcia: Wollastonite products, such as NYAD325 from NYCO Minerals Lewis, New York can be used to supply the calcia. An alternate, if one should be required, would be RT Vanderbilt Gouveneur, New York grade W10.

Iron Oxide: Red iron oxide such as ground hematite Densox from Bridgeville, Pennsylvania can be used for the iron oxide. There may be some silo-flow problems with this material. If additional chemical reduction of the glass is required, magnetite from American Minerals, King of Prussia, Pennsylvania, is partially reduced and appeared to have better powder flow properties. Iron III oxide from Alfa Aesar, Ward Hill, Massachusetts, has been used by.VSL and should be similar to the Densox material.

Lithia: Lithium carbonate from Chemetall - Cyprus Foote, Kings Mountain, North Carolina was selected. While this material is expensive, flow properties are good. An alternate at lower cost would be spodumene, F \& S International, Inc. concentrate which also has good flow properties. This material would be shipped from Western Australia. Some of the spodumene materials contain quartz. 
Magnesia: Olivine, grade \#180 from Unimin Corp, Hamilton Washington should provide a good source of magnesia. The material does contain trace amounts of nickel and chrome but these are locked into the crystalline structure of the mineral. This mineral also contains a small amount of quartz.

Silica: Sil-Co-Sil 75 supplied by U.S. Silica out of Mill Creek, Oklahoma appears to be the closest, high purity source of silica. The material should flow reasonably well and still be dispersible in the slurry. Caution should be taken with this material to avoid inhalation. If there are special requirements, such as shipment in super sacks, a very similar product is available from the U.S. Silica out of Pacific, Missouri. A less pure silica in a coarse grade, containing some alkali is available from Unimin Corp out of Byron, California.

Titania: A high purity grade titania (99.5\% TiO2), such as Kronos 1000 supplied by Kronos Inc., out of Houston, Texas, could be used to supply titania to the glass. This product has a dispersing agent applied to improve dispersion in wet processes. There is a high probability of silo problems unless there is extra attention to design of the silo / hopper for this material. An alternative and less costly material is the VSL recommended, airfloated rutile (95\% TiO2) from Chemalloy Company out of Bryn Mawr, Pennsylvania. Another ore product is ilmenite (65\%TiO2) from RGC Sands, out of Jacksonville, Florida. These materials may contain some free quartz.

Zinc Oxide: The selected material for zinc oxide is Denzox 730 supplied by Eagle Zinc Co. out of Hilsboro, Mlinois. Zinc oxide is a dense, refractory oxide which requires fine particle size to disperse in the slurry. There is a high probability of handling problems with this material and special and care should be taken in engineering the handling system. The material contains trace amounts of the hazardous metal oxides of lead and cadmium. There are other sources for this material, such as Zinc Corporation of America, Monaca, Pennsylvania.

Zirconia: The selected material for zirconia is a zircon flour such as the 325 mesh flour from Elf Atochem out of Andrews, South Carolina. This material should be fine enough to disperse in the slurry and melt into the glass. There may be some silo problems with this material and there is also some quartz present in this material. There are other suppliers for this type of material such as American Minerals, King of Prussia, Pennsylvania.

\section{CONCLUSIONS}

Twenty nine glass former, candidate powders were selected and characterized for their physical properties, powder flow characteristics, and durability in alkaline solution. A particular glass former was selected for each of the ten oxide classes required for the Envelope A, B, and C slurry mixtures. In some cases, alternates were included, and the justification for their inclusion was provided. It was determined that five of the fine grade, glass formers may cause flow problems when stored in silos and hoppers. The problem glass formers were kyanite, zircon flour, titania, zinc oxide, and iron oxide. 
The blends of glass formers were borderline on their powder flow properties, but one of the blends ( $\mathrm{B}$ envelope) did clump badly during long-term ( 30 day) storage.

For the design of the handling system, it may be possible to consider making a series of smaller blends and transferring these to the blend silo. This would reduce the size and cost of the weighing and transport equipment. Screw feeders should be considered as a replacement for the rotary feeders over the mixing tanks. This change should be considered, unless the rotary design is required for safety reasons. The BNFL proposed blending of a single master batch of material prior to feeding to the waste feed mixer tank would reduce or eliminate the problem of material segregation. The approach of feeding one master batch to the waste tank would improve the ability to predict glass composition.

\section{FUTURE DEVELOPMENT}

Additional evaluation of alternate materials and the blends after various storage times and temperatures should be considered.

The process area within the glass former handling system flow diagram, which appears to be of greatest concern, appears to be the feeding of the blended material to the waste solution tank. SRTC recommends that consultants in the field of powder flow be brought into the team to gain from their vast experience. It is recommended that a "Request for Proposals" be issued, either from SRTC or from BNFL Richland, to obtain the services of either, Jenike Johanson Inc., Westford, MA or Diamondback Technology (JR Johanson, Inc.) San Luis Obispo, California. Both have pilot facilities in San Luis Obispo, California which could support the vitrification effort. There may be other specialists who could be included, but these two are prominent in the field of flow properties of powders in hoppers and silos. The selected firm should analyze the problem glass formers and the blends and make recommendations on hopper design, feeder designs, and mixing of the materials. These two companies are consulting firms and not vendors of equipment.

Two commercial vendors, which supply information and support for pneumatic transfer and mixing, are Whirl-Air Flow Inc. Minneapolis, MN or Dynamic Air Conveying, St. Paul, MN. Another equipment supplier of possible interest is Toledo Scale of Toledo, Ohio, which has experience in automated weighing and recording of recipes. 
25

BNF-003-98-0188

Revision 0

APPROVALS

R.z Shumache

R.F. Schumacher, Principal Investigator

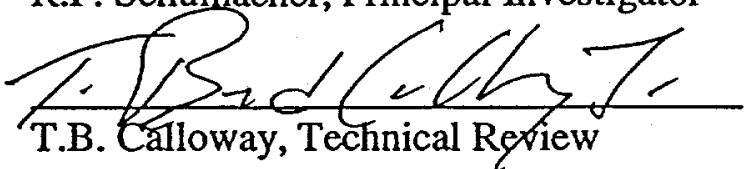

T.B. Calloway, Technical Reriew
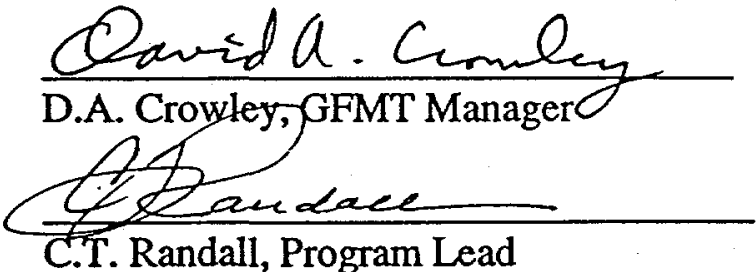

Entieet pratert

E.W. Holtzscheiter, ITS Manager
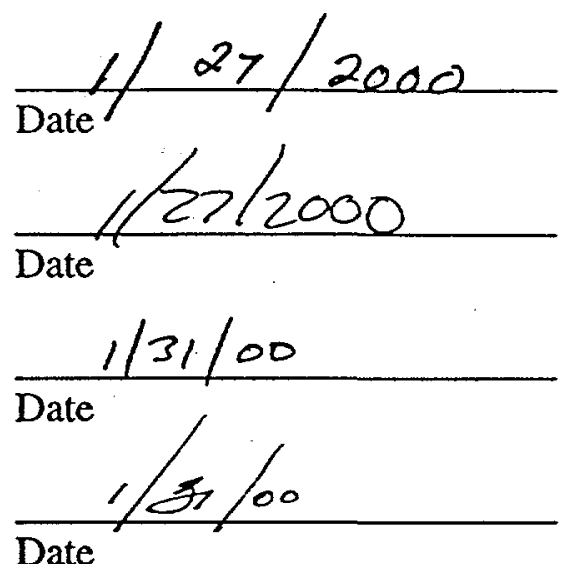

Date

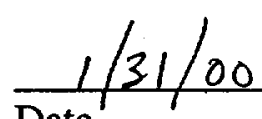

Date 


\section{REFERENCES}

1. P. Johnson, System 640: Glass Former Handling System Description, BNFLSDW375SH-PR00004, September 1, 1999.

2. J.A.H. deJong, A.C. Hoffmann, \& H.J. Finkers, "Properly Determine Powder Flowability to Maximize Plant Operation," Chem. Eng. Prog., page 25-34, April, 1999.

3. E.W. Merrow, "Estimating Startup Times for Solids-Processing Plants," Chem.Eng., page 89 , October $24,1988$.

4. RF. Schumacher, "Task Technical and Quality Assurance Plan for LAW Vitrification, Glass Formers Feed Preparation-TWRS Part 1B," BNFL-003-98-0057, Rev. 0, April 1999.

5. J.R. Johanson, "The Johanson Indicizer® How They Work and Their Uses," Annual Meeting of International Fine Particle Research Institute, Pasadena, CA, July 1, 1993.

6. F.V. Fooley, "The Handbook of Glass Manufacture," Volume I, Chapter 1, Books for Industry, Inc. New York, N.Y., 1974. 


\section{DISTRIBUTION:}

N. Lockwood, BNFL, Richland, WA

G. McArthur, BNFL, Richland, WA

P. Johnson, BNFL, Richland, WA

I. Pegg, VSL, Washington, DC

I. Mueller, VSL, Washington, DC

E.W.Holtzscheiter, WSRC, 773-A

D.A. Crowley, WSRC, 773-43A

C.T. Randall, WSRC, 773-42A

H.F. Sturm, WSRC, 773-A

T.B. Calloway, WSRC, 704-T

E.K. Hansen, WSRC, 704-T

C.L. Crawford, WSRC, 773-41A

J.R. Zamecnik, WSRC, 773-41A

D. Blankenship, WSRC, 773-41A

BNFL File, 773-41A, B. Skwarek, Rm 260 